\title{
DIMENSI HUMANITARIAN DALAM SISTEM EKONOMI ISLAM
}

\author{
Oleh: Rahmani Timorita Yulianti*
}

Abstract

Islamic economic system has divinity and humanity moral character. Islam has an economic system which applies resources given by Allah to meet the basic needs of human and gives them good life. Based on this view, the writer stresses that Islamic economic system needs to be fulfilled by human dimension in all fields of economic such as production, consumption, distribution, and circulation. On this frame, this article tries to identify the application of humanity principles into Islamic economic system related to activities in production, consumption, distribution, and circulation field.

a)

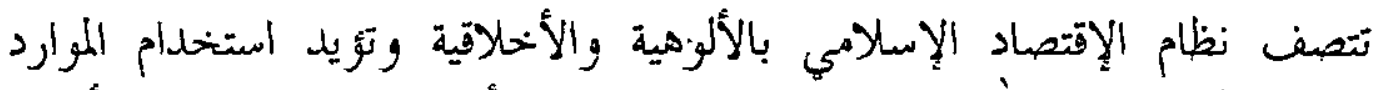

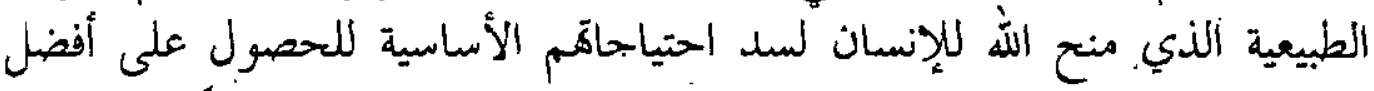

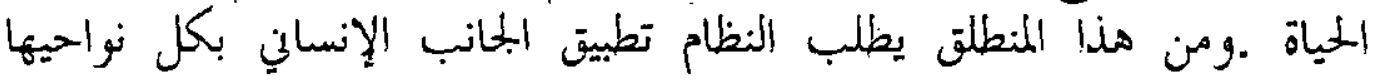

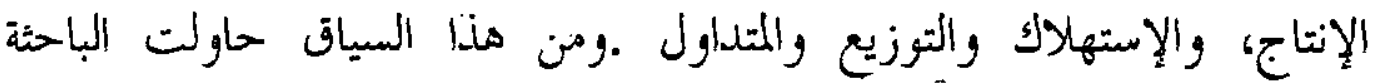

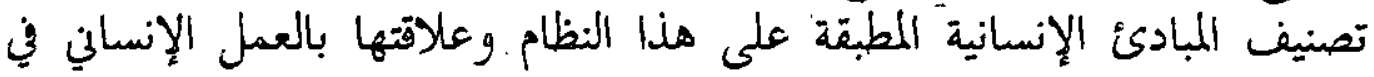

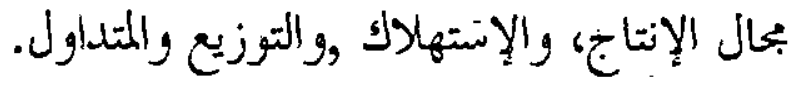

Kata kunci: humanisme, produksi, konsumsi, distribusi, sirkulasi

-Penulis adalah Dosen FIAI UII Jurusan Syari'ah' 


\section{A. Pendahuluan}

Kemanusiaan adalah salah satu nilai dasar yang dijadikan pedoman dalam kehidupan berbangsa, bernegara dan bermasyarakat. Prinsip kemanusiaan yang mungkin terjemahan dari humanisme atau humanitarian - meminjam istilah Julien Benda mengandung ciri-ciri tertentu, ${ }^{1}$ pertama, mengandung nilai keadilan yakni kemunusiaan yang berkeadilan. Kedua, mengandung nilai keberadaban, yakni kemanusiaan yang berkeadaban. Makna kemanusiaan kerap kali lebih jelas jika berhadapan dengan kasuskasus yang bertentangan dengan perikemanusiaan. ${ }^{2}$

Berbeda dengan pandangan humanisme bahwa "manusia itu adalah ukuran dari segala hal', pusat dari arti penting (significance) dan wadah dari segala kebajikan, maka Islam menempatkan kemanusiaan sebagai sekunder dari nilai tauhid. Ketuhanan yang dalam kehidupan sehari-hari diekspresikan sebagai Kebenaran, Keadilan dan Keindahan. Tauhid adalah sumber dari prinsip kemanusiaan.

Kemanusiaan adalah konsekuensi dari Ketuhanan. Karena itu Tuhanlah yang paling berhak menilai dan menempatkan manusia di antara semua makhluk-Nya. Atas dasar itu, maka sesungguhnya kehidupan manusia itu dimuliakan oleh Allah, ${ }^{3}$ karena salah satu prinsip ajaran kemanusiaan Islam adalah pemuliaan hidup.

Sebenarnya sumberdaya alam yang dianugerahkan oleh Allah kepada manusia secara kuantitas dan kualitas mencukupi bahkan melimpah ruah, tidak hanya bagi manusia tetapi juga bagi makhluk-makhluk lainnya. Tetapi manajemen terhadap sumberdaya tersebut oleh suatu kesatuan sosial dan politik kerap kali justru menciptakan kelimpahan yang berlebihan di satu pihak, dan kelangkaan serta kekurangan pada pihak lain. Bahkan, bisa terjadi perbedaan yang mencolok ( $g a p$ ) antara yang kaya yang sedikit jumlahnya dengan yang miskin yang besar jumlahnya. Ilmu ekonomi diciptakan untuk mengatur pengembangan sumberdaya dan distribusinya untuk seluruh manusia, setidak-tidaknya dalam kesatuan-kesatuan tertentu.

Butir kedua dalam ajaran kemanusiaan Islam adalah persamaan kedudukan manusia di hadapan Allah. ${ }^{4}$ Namun dalam kenyataannya, telah terjadi kelas-kelas sosial dalam masyarakat, seperti diperlihatkan dalam sistem kasta. Marx mengatakan bahwa setiap masyarakat dalam tahap perkembangan masyarakat itu selalu terdiri dari dua kelas yang antagonis, yakni kelas yang menindas dan yang ditindas. Dalam sosiologi-

'Pembahasan lebih lanjut lihat M. Dawan Rahardjo, 1999, Islam dan Transportasi Sosial Ekonomi, Jakarta, hal. 49.

${ }^{2}$ Ibid., hal. 50

${ }^{3}$ Q.S. al-Isrâ': 70 .

${ }^{4}$ Abdul Azis Dahlan, et, al, (ed.), Ensiklopedia Hukum Islam, Jakarta: PT. Ichtiar Baru Van Hoeve, hal. $124 \dot{9}$. 
ekonomi juga dikenal stratifikasi masyarakat berdasarkan tingkat pendapatan atau tingkat kemakmuran. Di tingkat nasional atau dunia terdapat pembagian masyarakat, paling tidak dalam tiga strategi, yaitu lapisan yang paling miskin dan papa (the desititute), lapisan miskin (the poor), lapisan tengah (the middle income group) dan lapisan kaya (the rich), bahkan sekarang ada pula lapisan yang teramat kaya (super rich). ${ }^{5}$

Kondisi tersebut bertentangan dengan prinsip persamaan kedudukan manusia, karena dengan tingkat kekayaan atau pendapatan yang berbeda secara mencolok itu persamaan kedudukan menjadi tiada. Ketiadaan persamaan itu merupakan akibat maupun sebab dari sistem perbudakan atau dominasi ( $a l$-riqâb) yang bersifat menindas.

Meskipun demikian, Islam juga mengajarkan kebebasan dan keterbukaan akses terhadap sumberdaya dalam mencari rezeki. ${ }^{6}$ Oleh karena itu, maka setiap orang dimotivasi untuk mengerjakan sesuatu guna memperoleh hasil atau prestasi. Sebagai konsekuensinya, akan terjadi persaingan antara individu dalam mengerjakan dan meraih sesuatu hasil kerja dan prestasi. Kebebasan tersebut, yang merupakan hak azasi manusia bisa menimbulkan ketidaksamaan hasil. Timbulnya pelapisan masyarakat berdasarkan perbedaan tingkat pendapatan tak bisa dihindarkan. Dalam hal ini Islam dapat menerima perbedaan dalam perolehan rezeki dan kekayaan.

Namun Islam atas dasar prinsip keadilan, yakni untuk menciptakan keseimbangan baru dalam masyarakat, menetapkan prinsip "pembersihan" harta benda, berupa zakat (pembersihan harta). Prinsip ini juga berakar dari paham kemanusiaan, yakni supaya kemanusiaan yang pincang akibat kemiskinan dapat dipulihkan kembali. ${ }^{\text {? }}$

Dengan demikain, maka prinsip kebebasan dan keadilan, juga merupakan bagian ketiga dan keempat dari kemanusiaan yang utuh. Prinsip kemanusiaan yang kelima adalah kemanusiaan umat manusia. Prinsip kesatuan ini perlu dikemukakan, karena manusia dalam kenyataannya terbagi ke dalam suku-suku dan bangsa-bangsa. Selain itu manusia merupakan elemen hidup dan tidak dapat dikesampingkan dari sebuah sistem ekonomi.

Oleh karena itu, yang diperlukan adalah peningkatan moral individu yang mengubah keselurụhan pandangan manusia tentang kehidupan dan memotivasinya untuk bertindak secara benar berdasarkan nilai-nilai kemanusiaan. Ia harus menyediakan suatu sistem ekonomi yang manusiawi dan adil sehingga merestorasi martabat manusia. ${ }^{8}$ Akan tetapi, suatu pertumbuhan ekonomi yang realistis bisa jadi tidak membantu mengurangi angka pengangguran kecuali jika terdapat gerakan serentak menuju kepada teknologi

${ }^{5}$ M. Dawam Rahardjo, op. cit. hal. 53.

${ }^{6}$ Q.S. al-Najm: 39.

${ }^{7}$ Adiwarman Azwar Karim, 2001, Sejarah Pemikiran Ekonomi Islam, Yogyakarta: Pustaka Pelajar, hal. 34.

${ }^{8} \mathrm{M}$. Umer Chapra, 2000, Sistem Moneter Islam, Jakarta: GIP, hal. xxv. 
yang kondusif bagi terciptanya kesempatan kerja penuh, atau dengan kata-kata Schumacher, "suatu teknologi dengan wajah manusia"."

Barangkali hal ini menuntut penerapan dimensi manusia dalam semua bidang garap ekonomi yaitu produksi, konsumsi, distribusi dan sirkulasi. Dalam kerangka itulah, tulisan ini mencoba mengidentifikasi penerapan prinsip-prinsip kemanusiaan dalam suatu sistem ekonomi Islam kaitannya dengan aktivitas di bidang produksi, konsumsi, distribusi, dan sirkulasi.

\section{B. Sistem Ekonomi Bercirikan Kemanusiaan}

Sistem ekonomi Islam mempunyai ciri ketuhanan dan moral, selain itu juga berkarakter kemanusiaan. Mungkin sebagian orang beranggapan bahwa kemanusiaan bertolak belakang dengan ketuhanan sehingga keduanya tidak bisa digabungkan. Persepsi tersebut tidak benar. Setidaknya, mereka yang menduga seperti itu lupa bahwa ide kemanusiaan berasal dari Allah. Allahlah yang memuliakan manusia dan menjadikannya khalifah di bumi.

Tujuan ekonomi Islam adalah menciptakan kehidupan manusia yang aman dan sejahtera. Yang dimaksud manusia di sini ialah semua golongan manusia, baik sebagai individu atau sebagai anggota masyarakat. Jika sistem ekonomi Islam itu bersandarkan pada nash al-Qur'an dan al-Sunnah yang berarti nash ketuhanan - maka manusia berperan sebagai yang diserukan dalam nash itu. Dalam ekonomi manusia adalah tujuan dan sarana. Manusia diwajibkan melaksanakan tugasnya terhadap Tuhannya, terhadap dirinya, keluarganya, umatnya dan seluruh umat manusia. Manusialah yang menjadi wakil Allah di bumi ini, ${ }^{10}$ serta memakmurkannya. ${ }^{11}$

Dengan demikian, dalam ekonomi Islam, manusia dan faktor kemanusiaan merupakan unsur utama. Faktor kemanusiaan dalam ekonomi Islam terdapat dalam kumpulan efika yang terdapat di dalam al-Qur'an dan hadis serta tertulis di dalam bukubuku klasik (turâts) yang mencakup etika, kebebasan, kemuliaan, keadilan, sikap moderat, dan persaudaraan sesama manusia.

Islam juga menganjurkan kasih sayang sesama manusia terutama kaum lemah, anak yatim, miskin papa, dan yang terputus dalam perjalanan. Islam mengajarkan sikap bertenggang rasa kepada para janda, tua renta, dan orang yang tidak sanggup bekerja. Buah yang dipetik dari etika ini ialah diakuinya oleh Islam milik individu, dengan syarat barang itu diperoleh dengan jalan halal. Islam juga menjaga milik individu dengan segala

${ }^{9} \mathrm{~F}$. Schumacher, 1973, Small is Beautiful, London: Blond and Briggs, hal. 18

${ }^{10}$ Q.S. al-Baqarah: 30.

"Q.S. Hûd: 61. 
undang-undang dan etika. Hak manusia untuk menjaga hak milik dan hartanya dari siapa saja yang ingin merusak.

Salah satu tanda yang jelas tentang ciri kemanusiaan pada ekonomi Islam ialah penyediaan sarana yang baik untuk manusia. Sebagai tatanan ekonomi, Islam menganjurkan manusia bekerja dan berusaha. Bekerja dan berusaha yang dilakukan oleh manusia itu diletakkan Allah pada timbangan kebaikan mereka. Tidak aneh apabila seorang muslim yang menjunjung kehidupan yang baik ini akan mendapatkan ganjaran bila ia tekun bekerja. Dalam rangka menjunjung kehidupan, manusia telah dikaruniai berbagai kenikmatan untuk memenuhi kebutuhannya baik material maupun spiritual.

\section{Dimensi Manusia dalam Bidang Produksi, Konsumsi, Distribusi dan Sirkulasi}

1. Dimensi manusia dalam bidang produksi

Sebagian penulis tentang teori ekonomi Islam berpendapat bahwa ekonomi Islam hanya memfokuskan perhatian kepada distribusi harta, dan tidak mementingkan masalah produksi. Dengan kata lain, ekonomi Islam hanya memperhatikan distribusi harta secara adil dan merata, namun sama sekali tidak berhubungan dengan produksi.

Perkataan ini tidak sepenuhnya benar. Jika yang dimaksud dengan "produksi" adalah sarana, prasarana, dan cara kerja secara umum, maka ungkapan di atas dapat diterima. Namun, jika yang dimaksud dengan produksi adalah tujuan, etika, dan peraturan yang berhubungan dengan produksi, maka ungkapan di atas sulit diterima.

Para ahli ekonomi menetapkan bahwa produksi terjadi melalui peranan tiga atau empat unsur yang saling berkaitan yaitu alam, modal, dan bekerja. Sebagian ahli lain menambahkan unsur disiplin. Para ekonomi muslim berbeda pendapat tentang apa yang ditetapkan Islam dari unsur-unsur ini. Sebagian dari mereka menghapuskan salah satu dari empat unsur itu berdasarkan teori, pertimbangan, dan hasil penelitian mereka. Menurut Qardawi jauh dari pembagian yang dilakukan oleh para ekonom kapitalis pembagian di atas berperan dalam proses produksi tetapi unsur yang terutama adalah alam dan bekerja. ${ }^{12}$

Yang dimaksud dengan alam atau bumi adalah segala kekayaan alam yang diciptakan Allah agar bisa dimanfaatkan oleh manusia sebagai bekal yang mereka butuhkan. Yang dimaksud dengan bekerja adalah segala usaha maksimal yang dilakukan manusia, baik lewat gerak anggota tubuh ataupun akal untuk menambah kekayaan, baik dilakukan secara perseorangan ataupun secara kolektif, baik untuk pribadi ataupun untuk orang lain (dengan menerima gaji).

${ }_{12}$ Yusuf Qardawi, 1997, Norma dan Etika Ekonomi Islam, Jakarta: GIP, hal. 104. 
Produktifitas timbul dari gabungan kerja antara manusia dan kekayaan bumi. Adapun unsur lainnya, seperti disiplin, tidak lebih daripada strategi dan pengawasan, sementara modal tidak lebih daripada aset, baik berbentuk alat ataupun bangunan yang semuanya merupakan hasil kerja manusia. Ringkasnya, modal adalah pekerjaan yang terpendam. Jadi, sendi terpenting dan rukun yang terutama dalam produksi adalah bekerja Bekerja dalam mengolah bumi hingga menghasilkan harta dan apaapa yang baik. ${ }^{13}$ Pada unsur pemanfaatan sumber daya alam oleh manusia dan aktivitas kerja yang dilakukan oleh manusia sehingga terbentuk produktivitas inilah, dimensi kemanusiaan dapat dikembangkan.

Allah menjamin rezeki seluruh makhluk hidup yang merangkak di atas bumi, dan sudah menjadi Sunnatullah bahwa jaminan rezeki itu tidak akan mungkin di dapat kecuali derigan berusaha dan bekerja. ${ }^{14}$

Oleh sebab itu, Islam menganjurkan umatnya untuk memproduksi dan berperan dalam berbagai bentuk aktivitas ekonomi. Pada dasarnya, pekerjaan duniawi tidak hanya bermanfaat bagi individu pelakunya, tetapi juga penting untuk mencapai kemaslahatan masyarakat secara umum. Tidak logis jika dalam kehidupan di dunia ini manusia selalu mengambil tanpa pernah memberi apa pun kepada orang lain atau masyarakat, baik berbentuk ilmu ataupun tenaga. ${ }^{15}$

Berdasarkan tuntutan syari'at, seorang muslim diminta bekerja untuk mencapai beberapa tujuan. Yang pertama adalah untuk memenuhi kebutuhan pribadi dengan karya yang halal, mencegahnya dari kehinaan meminta-minta, dan menjaga tangannya agar tetap berada di atas. Dalam diwajibkan bekerja bagi individu oleh Ișlam adalah dilarangnya meminta-minta, mengemis, dan mengharapkan belas kasihan orang. Yang kedua bekerja diwajibkan demi terwujudnya keluarga sejahtera. Islam mensyariatkan seluruh manusia untuk bekerja, baik laki-laki ataupun wanita, sesuai dengan profesi masing-masing.

Sedangkan yang ketiga bekerja ditujukan untuk kemaslahatan masyarakat. Walaupun seseorang tidak membutuhkan pekerjaan karena seluruh kebutuhan hidupnya telah tersedia, baik untuk dirinya maupun untuk keluarganya, ia tetap wajib bekerja untuk masyarakat sekitarnya. Yang keempat, seorang muslim tidak hanya bekerja demi mencapai manfaat komunitas manusia, tetapi ia wajib bekerja untuk kemanfaatan seluruh makhluk hidup, termasuk hewan.

Yang kelima, manusia bekerja untuk memakmurkan bumi. Memakmurkan bumi adalah tujuan dari maqâshid al-syarî̀ ah yang ditanam oleh Islam, disinggung

\footnotetext{
${ }^{13}$ Lihat Q.S. Hûd: 61; Q.S. al-Baqarah: 30; Q.S. Fâthir: 702.

${ }^{14}$ Q.S. al-Mulk: 15.

${ }^{15}$ Yusuf Qardawi, op. cit., hal. 108.
} 
oleh al-Qur'an, serta diperhatikan oleh para ulama. Di antara mereka adalah alImam al-Raghib al-Asfahani, ${ }^{16}$ yang menerangkan bahwa manusia diciptakan Allah hanya untuk tiga kepentingan. Kalau bukan untuk tiga kepentingan itu, maka ia tidak akan ada:
a. : Memakmurkan bumi
b. Menyembah Allah.
c. Khalifah Allah.

Adapun yang keenam, manusia bekerja untuk kerja. Ménurut Isłam, pada hakikatnya setiap muslim diminta untuk bekerja meskipun hasil pekerjaannya belum dapat dimanfaatkan olehnya, oleh keluarganya, atau oleh masyarakat; juga meskipun tidak satu pun dari makhluk Allah, termasuk hewan, dapat memanfaatkannya.

2. Dimensì manusia dalam bidang konsumsi

Mayoritas ahli ekonomi memfokuskan perhatiannya pada produksi. Mereka berusaha sekuat tenaga meningkatkan produksi serta memperbaiki kualitas serta kuantitasnya. Namun, bertambahnya hasil produksi tidak cukup untuk menciptakan manusia yang hidup aman dan sejahtera. Sebab, sangat mungkin produk ini baik -sebagian atau bahkan seluruhnya digunakan untuk urusan yang tidak bermanfaat bagi manusia, merusak jiwa dan akal, serta tidak membahagiakan keluarga dan masyarakat.

Memproduksi barang-barang yang baik dan memiliki harta adalah hak sah menurut Islam. Namun, pemilikan harta itu bukanlah tujuan tetapi sarana untuk menikmati karunia Allah dan jalan untuk mewujudkan kemaslahatan umum, yang memang tidak sempurna kecuali dengan harta yang dijadikan Allah bagi manusia sebagai dasar pijakan. Memiliki harta untuk disimpan, diperbanyak, lalu dihitunghitung adalah tindakan yang dilarang. Ia merupakan penyimpangan petunjuk Tuhan, sunnah mukmin, dan memungkiri keberadaan istikhlâf. ${ }^{17}$

Belanja dan konsumsi adalah tindakan yang mendorong masyarakat berproduksi hingga terpenuhi segala kebutuhan hidupnya. Jika tidak ada manusia yang tersedia menjadi konsumen, dan jika daya beli masyạrakat berkurang karena sifat kikir yang melampaui batas, maka cepat atau lambat, roda produksi niscaya akan terhenti, selanjutnya perkembangan bangsa pun terlambat.

Oleh sebab itu, beberapa negara industri berusaha memberi bantuan keuntungan kepada negara berkembang dengan jumlah puluhan bahkan ratusan juta dollar. Hal ini dilakukan bukan karena mereka suka berderma, bukan pula karena

${ }^{16}$ Lihat Zarî'ah llâ Mahârim al-Syarî' ah, Darul Wafâ', hal. 9-91.

${ }^{17}$ Q.S. al- $\underline{\text { Hadîd: }} 7$. 
ingin berbuat baik, tetapi semata-mata untuk menciptakan daya beli terhadap produkproduk mereka. ${ }^{18}$

Adapun konsekuensi dari harta benda yang diperoleh seseorang dari hasil usahanya tidak menimbulkan hak-hak istimewa kepadanya, sebaliknya manusia yang tidak memiliki harta bendapun tidak menjadi berkurang hak-hak kemanusiaannya dalam hidup masyarakat. Dengan demikian dimensi kemanusiaan dalam bidang konsumsi adalah, manusia kaya karena kekayaan yang dimilikinya tidak mempunyai hak lebih atas manusia yang lain, sebaliknya manusia yang miskin karena kemiskinan yang dialaminya, tidak berkurang hak-hak kemanusiaannya dari manusia yang kaya. Keduanya mempunyai kedudukan yang sama. Atas dasar demikian, Islam mengajarkan agar orang kaya jangan merasa lebih dari orang miskin, tetapi harus menunjukkan sikap kasih sayang, peduli dan tetap menghargai kedudukannya sebagai manusia. Sebaliknya orang miskin tidak diperbolehkan merasa lebih kecil dari orang kaya, sehingga menimbulkan perasaan dengki dan iri. ${ }^{19}$

Fenomena perbedaan perolehan hasil usaha, menimbulkan kewajiban bagi manusia untuk membelanjakan harta. Ini merupakan pertanda jelasnya perintah membelanjakan uang, bukan sekadar anjuran yang boleh dikerjakan atau ditinggalkan. ${ }^{20}$

Para mufasir berbeda penafsiran tentang maksud infak ini, apakah infak itu maksudnya zakat fardhu, sedekah sunat, atau menafkahkan harta untuk keluarga? Para pengamat condong mengatakan bahwa redaksi infak bertendensi seluruh bentuk infak, baik itu wajib ataupun sunat, untuk diri sendiri ataupun untuk keluarga, untuk masyarakat ataupun fi sabillillâh (jalan Allah).

Dari ayat al-Qur'an ini ditemukan bahwa al-Qur'an menetapkan infak berupa sebagian dari rezeki Allah. Artinya, yang dinafkahkan itu hanya sebagian, sedangkan sebagian lagi disimpan. Dalam hal ini, Islam menggariskan bahwa membelanjakan harta tidak boleh melampaui batas, misalnya menafkahkan harta untuk orang banyak dalam jumlah lebih besar daripada nafkah pribadinya. Peraturan ini ditetapkan agar ia dan keluarganya dapat hidup serba cukup, tidak mengemis kepada orang lain. Selain membelanjakan harta di jalan Allah, bentuk nafkah yang kedua adalah nafkah untuk diri sendiri dan keluarga yang ditanggungnya. Al-Qur'an juga tidak membenarkan kesengsaraan yang sengaja dijalani oleh seseorang dengan alasan untuk beribadah atau untuk menghemat uang. Sejalan dengan itu, Nabi pun melarang orang hal.9.

${ }^{18}$ Yusuf Qardawi, op. cit., hal. 138.

${ }^{19}$ Ahmad Azhar Basyir, 1981, Garis Besar Sistem Ekonomi Islam, Yogyakarta: FE UGM,

${ }^{20}$ Q.S. al-Baqarah:2; Q.S. Al-Nisâ’: 39. 
menjalani kesengsaraan dengan dalih seperti itu dan beliau memandangnya sebagai faktor yang membinasakan kehidupan manusia. ${ }^{21}$

3. Dimensi manusia dalam bidang distribusi

Di antara bidang yang terpenting dalam perekonomian adalah bidang distribusi, sehingga sebagian penulis ekonomi Islam memusatkan perhatiannya kepada bidang ini.

Dalam sistem ekonomi kapitalis, perdagangan terpusat pada distribusi pasca produksi, yaitu setelah mereka menghasilkan barang untuk suatu proyek. Pandangan mereka terfokus kepada uang atau harga. Dalam kaitan dengan distribusi hasil produksi, ditemukan adanya empat bagian:

a. Upah atau gaji untuk para pekerja. Yang biasa terjadi, para produsen memeras tenaga para buruh tanpa memberi upah yang seimbang.

b. Keuntungan sebagai imbalan modal yang dipinjam oleh pengelola proyek.

c. Sewa tanah yang digunakan untuk melaksanakan proyek itu.

d. Laba bagi para manajer yang mengelola, dan mengurusi pelaksanaan proyek, dan sebagai penanggung jawabnya.

Akibat perbedaan apa yang dimiliki masing-masing dari unsuṛ-unsur kerja sama dalam memproduksi maka berbeda pula pendapatan untuk masing-masing. Namun, Islam menolak keberadaan nomor dua dari empat hal di atas, yaitu keuntungan. Para ulama bermufakat begitu pula pengkajian-pengkajian fikih kontemporer bahwa keuntungan itu adalah bunga yang diharamkan. Adapun tiga bagian lainnya, Islam membolehkannya jika memenuhi syarat dan dijalankan sesuai dengan hukum.

Menurut paham ekonomi sosialis, produksi tunduk pada peraturan pusat. Seluruh sumber produksi adalah milik negara. Dasar distribusi barang ditetapkan oleh keputusan sidang di negara sosialis. Negaralah yang menyusun strategi produksi rakyat, juga menentukan garis-garis besar distribusi. Upah, gaji, bunga, laba, dan para manajer diatur oleh pemerintah. ${ }^{22}$

Ekonomi Islam bebas dari tindak kapitalis dan sosialis. Islam menerapkan filsafat dan tatanan yang berbeda dari kedua sistem tersebut. Islam memfokuskan perhatiannya pada distribusi sebelum membahas sektor produksi. Siapakah yang memilikinya? Dengan cara bagaimana produk distribusikan, dan apa saja kewajibannya?

${ }^{21}$ Lihat Hadis Riwayat Thabrani dari Ibnu Umar, Shahih Jamî' Shaghîr, No. 3045 dan 3039.

${ }^{22}$ Yusuf Qardawi, op. cit., hal. 201. 
Pemfokusan pada distribusi tidak berarti Islam tidak memperhatikan keuntungan yang diperoleh dari produksi. Islam memberikan gaji secara adi] kepada para pegawai dản buruh jika mereka melaksanakan tugas dengan sempurna, sebagaimana Islam dengan tegas menolak segala bentuk riba.

Distribusi ekonomi Islam berdiri di atas dua sendi, yaitu sendi kebebasan dan sendi keadilan.

a. Asas kebebasan

Sendi pertama distribusi adalah kebebasan. Mengapa tatanan Islam menetapkan kebebasan dalam kehidupan ekonomi manusia? Mengapa kediktatoran ekonomi yang selalu mencekik leher rakyat dan mengendalikan rezeki mereka menolak kebebasan ini? Jawabannya, hal itu kembali kepada dua hal. Pertama, percaya kepada Allah; kedua, percaya kepada manusia. ${ }^{23}$

1) Percaya kepada Allah dan Mengesakan-Nya

Inti kepercayaan kepada Allah di dalam Islam adalah tauhid (monoteisme), yaitu ungkapan "lâ ilâha illallâh" (Tiada Tuhan selain Allah). Namun, monoteisme ini tidak selesai dengan sekedar mengakui Allah sebagai satu-satunya zat yang menciptakan langit dan bumi serta apa yang diantara keduanya. Hakikat tauhid adalah mengesakan Allah dalam beribadah dan memohon pertolongan.

Islam datang membebaskan manusia dari penyembahan selain Tuhan Yang Maha Esa. Ia datang untuk menyampaikan misi bahwa semua manusia adalah sama. Semua saudara seperti anak-anak dalam satu keluarga. Oleh sebab itu, tidak seyogyanya manusia menyombongkan diri dan memeras sesama manusia. Adalah tidak wajar jika satu kelompok menganggap dirinya sebagai Tuhan yang pantas disembah oleh sebagian manusia yang lain.

2) Kepercayaan kepada Manusia

Islam menerapkan kebebasan karena ia menganjurkan kepada umatnya untuk percaya kepada Allah. Islam juga menetapkan kebebasan karena mengakui eksistensi manusia, mengakui fitrah mereka untuk menyembah Allah. Islam mengakui kemuliaannya dan keahliannya. Karena itulah, Allah mengangkat manusia sebagai khaliffatullâh (pelaksana tugas dari Allah) di muka bumi.

b. Pengakuan hak milik pribadi, tanda pertama kebebasan

Kebebasan hak pemilikan yang khusus adalah tanda pertama kebebasan. Peraturan Islam mengakui hak pemilikan khusus adalah untuk memelihara naluri manusia yang tumbuh sejak kecil, yaitu naluri senang memiliki. Maka tidaklah 
aneh jika peraturan Islam mengakui eksistensi pemilikan harta, bahkan menganjurkan manusia agar mereka memilikinya, dan melindungi hak miliknya itu dari orang-orang zalim yang akan merampasnya. Tanda kebebasan yang lain adalah adanya perbedaan perolehan rezeki dan bervariasinya jumlah penghasilan setiap individu.

Sistem sosialis mengingkari variasi rezeki manusia dan pemilikan-harta benda. Sistem sosialis mengajak manusia menolak pemilikan harta benda oleh perseorangan karena ia merupakan langkah awal menuju persamaan dan menghilangkan segala bentuk perbedaan.

Pada hakikatnya, persamaan yang mereka dengung-dengungkan bertolak belakang dengan tabiat manusia dan bertolak belakang dengan hukum alam. Apabila persamaan dalam rezeki dan derajat merupakan suatu hikmah maka seharusnya berlaku terhadap apa yang lebih penting daripada rezeki dan harta yaitu bakat, kekuatan, kemampuan secara umum dan khusus, kekuatan akal jiwa dan jasmani, sehingga di kalangan manusia tidak terdapat orang yang berbadan tinggi besar dan pendek kecil, jenius dan bodoh, kuat dan lemah. Tetapi semua itu adalah ciptaan Allah. Tiap penentangan terhadap tabiat dan fitrah Allah pada manusia dan kehidupan akan berakibat kerugian dan kekalahan.

Jika pengakuan terhadap hak milik pribadi atau khusus merupakan fenomena pertama kebebasan, maka warisan adalah bukti hak pemiliknya yang paling menonjol.

Menurut Qardawi ada dua hak yang utama: Hak yang tetap dan kekal, Hak bebas membelanjakan harta milik. ${ }^{24}$ Arti hak tetap dan kekal adalah kekalnya pemilikan dan kekalnya keberadaan barang dan bisa jadi hakiki dan bisa jadi majazi (anggapan atau figuratif):

1) Hakiki, jika harta yang dimiliki bisa dipergunakan dan dibelanjakan untuk membeli barang-barang yang bersifat temporer, seperti makanan, pakaian, dan perabot rumah tangga dan di bawah kekuasaannya selama hidupnya.

2) Pemilikan hakiki bisa berubah menjadi majazi dalam dua keadaan.

a) Harta milik yang bisa habis sedangkan pemiliknya belum sempat menggunakannya.

b) Harta yang tidak bisa dibelanjakan, seperti rumah dan tanah yang ditinggal mati pemiliknya.

Dalam pemilikan yang terakhir ini, tergambar pemilikan secara majazi. Berbagai syariat dan aliran berusaha meletakkan hukum pemilikan pribadi ini dan hukum perpindahan barang yang dimiliki oleh orang sesudahnya, berupa 
bangunan dan harta benda. Perpindahan ini tercapai dengan cara wasiat yang disampaikan oleh pemilik harta kepada orang lain setelah ia wafat, yang ditentukan semasa ia hidup. Atau, warisan diterima oleh anggota keluarga yang ditinggalkan atau oleh kaum kerabat yang menurut ketentuan Islam adalah yang paling berhak menerima harta yang ditinggalkan itu.

Dalam kedua bentuk pemilikan ini, perpindahan barang dari orang yang meninggal kepada penerima wasiat atau ahli waris bukanlah pemilikan baru jika ditinjau dari segala segi. Perpindahan harta ini sekadar perpanjangan usaha si wafat kepada penerima wasiat untuk mencapai tujuan yang diinginkannya. Dengan kata lain, ahli waris (penerima warisan) adalah bentuk baru orang yang wafat berdasarkan hubungan darah yang sangat erat. Seakan-akan ahli waris adalah duplikat pemilik pertama, dan seakan-akan pemilik pertama masih hidup walaupun berganti dengan kemasan baru. ${ }^{25}$

Dalam bidang distribusi, warisan dalam syariat Islam termasuk sarana untuk menyebarkan harta benda kepada orang banyak yaitu memindahkan harta benda dari milik seseorang kepada beberapa orang. Syari'at Islam tidak membagikan harta warisan hanya kepada anak sulung atau kepada anak lakilaki tanpa membagikan kepada wanita, atau kepada yang besar-besar tanpa membagikan kepada anak-anak kecil kecuali kepada yang mampu mengangkat senjata, dengan kata lain anak-anak kecil lelaki maupun perempuan yang tidak ikut berperang tidak men-dapatkan warisan.

Dengan demikian, dapat disimpulkan bahwa Islam tidak membiarkan sentralisasi harta warisan pada seorang atau dua orang saja. Sebaliknya, Islam membagi-bagikannya kepada orang banyak yang berhak menerimanya, baik ahli waris yang utama atau 'ashabah. Adapun kaum kerabat yang tidak mendapat warisan dan fakir miskin yang membutuh-kan harta dan yang hadir sewaktu dilakukan pembagian warisan bisa memperoleh bagian dari warisan tersebut. ${ }^{26}$ Sehubungan dengan asas kebebas-an ini, kebebasan ekonomi yang disyariatkan Islam bukanlah kebebasan mutlak yang terlepas dari berbagai ikatan. Kebebasan tersebut adalah kebebasan yang terbatas, terkendali dan terikat dengan keadilan yang diwajibkan Allah.

Meskipun terdapat perbedaan dalam perolehan rezeki sesuai dengan profesi dan keahlian, maka prinsip keadilan yang diserukan Islam mewajibkan

${ }^{25}$ Lihat buku Ali Abdul Wahid, Hak-hak Manusia dalam Islam, Mesir: Nahdah, Cet V, ${ }^{26}$ Q.S. al-Nisâ': 8. 
mereka yang tidak mendapatkan pekerjaan akan ditelantar-kan dan tertindas oleh golongan ekonomi kuat yang terlalu berambisi. Islam mewajibkan golongan ekonomi kuat agar mengulurkan tangan kepada kaum yang lemah ( $d h u$ 'afâ') agar mereka bisa berdikari.

Pada pokoknya orang-orang yang mampu bekerja harus bekerja agar tidak membebani masyarakat dengan mencari yang halal dan masyarakat harus membantu mereka. Jika mereka lemah dan tidak sanggup lagi bekerja, maka mereka berhak atas harta orang kaya untuk mencukupi kebutuhan pokoknya sebagaimana dinyatakan oleh para fuqaha'. Di antara kebutuhan pokok yang harus terpenuhi adalah sandang, pangan, papan, dan obat-obatan.

Layanan dan jaminan masyarakat ini pada zaman sekarang terkenal dengan istilah "solidaritas sosial". Sebagian orang menduga bahwa solidaritas sosial adalah hasil modernisasi, dan produk Barat. Padahal, Islam telah mewajibkannya sejak empat belas abad yang lalu. Jika diamati konsep Islam maka tampak jelas bahwa zakat yang merupakan sumber dana pertama untuk membiayai solidaritas sosial dan santunan ini bukanlah nilai yang sepele. Zakat yang diwajibkan itu sepuluh atau lima persen dari hasil tanaman.

4. Dimensi manusia dalam bidang sirkulasi

Sirkulasi adalah pendayagunaan barang dan jasa lewat kegiatan jual beli dan simpan pinjam melalui agen, koperasi, lembaga keuangan baik sebagai sarana perdagangan atau tukar-menukar barang. ${ }^{27}$ Dimensi manusia dalam bidang sirkulasi menurut ekonomi Islam sangat fleksibel. Ia berbeda dengan ciri sosialis yang menolak kebebasan pasar dan tidak sama dengan sistem kapitalis yang menganut pasar bebas.

Dalam sistem kapitalis, yang kuat memeras yang lemah yang cerdik menipu yang bodoh. Sementara, dalam Islam berpegang pada asas kebebasan dalam tatanan mu'amalah, termasuk dalam aktivitas pasar. Manusia bebas membeli, menjual, serta tukar-menukar barang dan jasa. Manusia menawarkan dan menjual.barang miliknya dan membeli barang kebutuhannya. Pada dasarnya Islam menganut prinsip kebebasan terikat, yaitu kebebasan berdasarkan keadilan. Di dalam peraturan sirkulasi atau perdagangan Islami terdapat norma, etika agama, dan perikemanusiaan yang menjadi landasan pokok bagi pasar Islam yang bersih. Norma tersebut adalah: ${ }^{28}$

a) Manusia harus menegakkan larangan memperdagangkan barang-barang yang diharamkan.

b) Manusia harus bersikap jujur, benar dan amanah dalam bertransaksi

${ }^{27}$ Yusuf Qardawi, op. cit., hal. 171.

${ }^{28}$ Lihat Q.S. al-Muthaffifîn: 2-3; Q.S. al-Nisâ': 58; Q.S. al-Qashash: 8; Q.S. al-Jumu'ah: 9-

11. 
c) Manusia harus menegakkan keadilan dan menjauhi bunga/riba

d) Manusia harus menerapkan kasih sayang dan mengharamkan monopoli

e) Manusia harus berpegang pada prinsip bahwa perdagangan adalah bekal menuju akhirat apabila menerapkan norma-norma tersebut.

\section{Penutup}

Dari paparan di atas dapat disimpulkan beberapa hal sebagai berikut: Pertama, Islam menyediakan suatu sistem ekonomi yang meniscayakan penggunaan sumber-sumber daya yang diberikan Allah untuk memenuhi kebutuhan-kebutuhan pokok umat manusia dan memberikan kepada mereka kondisi kehidupan yang baik. Kedua, sistem ekonomi Islam bukan hanya berlandaskan kepada nilai-nilai Ketuhanan dan moral, tetapi juga berdasarkan kepada prinsip kemanusiaan. Dimensi manusia sangat diperhatikan dalam rangka melakukan aktivitas ekonomi seperti produksi, konsumsi, distribusi dan sirkulasi.

\section{DAFTAR PUSTAKA}

Basyir, Ahmad Azhar, 1981, Garis Besar Sistem Ekonomi Islam, Edisi Revisi, FE UGM, Yogyakarta.

Chapra, M. Umer, 1997, al-Qur'an Menuju Sistem Moneter yang Adil, penerjemah Lukman Hakim, Yogyakarta:PT. Dana Bhakti Prima Yasa.

1999. Islam dan Tantangan Ekonomi. Surabaya: Risalah Gusti.

Dahlan, Abdul Azis (ed.), 1996, Ensiklopedi Hukum Islam, Jakarta: Ichtiar Baru Van Hoeve.

Ibrahim, Taher, 1967, Pembahasan Ekonomi Islam, Marx dan Keynes, Jakarta: Bulan Bintang..

Kahf, Monzer. 1995. Ekonomi Islam; Telaah Analitik Terhadap Fungsi Sistem Ekonomi Islam. Yogyakarta: Pustaka Pelajar.

Karim, Adiwarman Azwar, 2001, Sejarah Pemikiran Ekonomi Islam, Yogyakarta: Pustaka Pelajar. 
Mannan, M. Abdul. 1997. Ekonomi Islam; Teori dan Praktek Yogyakarta: Dana Bakti Wakaf.

Nabhani, Taqyuddin al-, 1996, Membangun Sistem Ekonomi Alternatif Perspektif Islam, Surabaya: Risalah Gusti.

Qardawi, Yusuf, 1997, Norma dan Etika Ekonomi Islam, Jakarta: GIP.

Rahardjo, M. Dawam. 1999. Islam dan Transformasi Sosial Ekonomi, Yogyakarta: Pustaka Pelajar.

Rahman, Afzalur, 1996, Doktrin Ekonomi Islam, Jilid 3, penerjemah Soeroyo dan Nastangin, Yogyakarta: Dana Bakti Wakaf. 